\title{
The Devil, Superstition, and the Fragmentation of Magic
}

\author{
SEAN ARMSTRONG \\ Toronto, Ontario
}

\begin{abstract}
Using mostly English sources of the witch hunt era, this article demonstrates that the "fragmentation of Renaissance occultism" argued by John Henry and others involved redefining the term "superstition." At the start of the witch hunt era, superstition was the antonym to religion; by the 1620s, when the witch hunt peaked, Francis Bacon was presenting his new philosophy as the antonym to superstition and its twin idolatry. This change in the signification of superstition was causally linked to the devil, who was both master and goal of all superstition and idolatry. Superstition was redefined and the devil was rethought as aspects of the same process, as critics of the witch hunt concluded that it was superstition to believe the devil could affect the natural order. The early stages of this redefinition drew on a concept from early classical natural philosophy that has been labelled "double determination" by G. E. R. Lloyd. Eventually the expanded concept of superstition became the counterfoil to the new philosophy.
\end{abstract}

Employant principalement des sources de la période de la chasse aux sorcières, cet article démontre que la "fragmentation de l'occultisme de la Renaissance », soutenu par John Henry et d'autres, impliquait une redéfinition du terme «superstition". Au début de la période de la chasse aux sorcières, superstition était antonyme de religion. Dès les années 1620, au summum de la chasse aux sorcières, Francis Bacon présentait sa nouvelle philosophie comme l'antonyme de la superstition et de l'idolâtrie qui lui associée. Ce changement dans la signification de la superstition était lié au diable, qui était à la fois maître et objectif de toute superstition et idolâtrie. La superstition est redéfinie et le diable repensé comme aspects du même processus, les critiques de la chasse aux sorcières ayant conclu qu'il était superstitieux de croire que le diable pouvait influencer l'ordre naturel. Les premières étapes de cette redéfinition s'inspiraient d'un concept de la philosophie naturelle antique intitulée "double determination " par G. E. R. Lloyd. Finalement, le concept élargi de superstition est devenu la souche de la nouvelle philosophie.

\section{The occult, the devil, superstition, and witchcraft}

istorians increasingly agree that the early Scientific Revolution was heav-
ily indebted to the occult or magical tradition in Renaissance Europe.
This tradition (more exactly, a congeries of traditions) was parsed out and
taken over piecemeal into the new philosophy, with some parts taken up and 
the rest discarded. John Henry has called this process "the fragmentation of Renaissance occultism." In related arguments, Stuart Clark has pointed to the collapse of the preternatural domain ruled by the devil, ${ }^{2}$ and Keith Hutchison has shown how the concept of occult qualities was rejected. ${ }^{3}$

Using well-known, mostly English sources, this article demonstrates that the processes just mentioned involved redefining the term "superstition." At the start of the witch hunt era, ca. 1430, superstition was the antonym to religion; by the 1620 s, when the witch hunt peaked, Francis Bacon saw superstition and its twin idolatry as the antonyms to his new philosophy. This change in the signification of superstition was causally linked to the fortunes of the devil, as he was the great lord of magic, both master and goal of all superstition and idolatry. Since the 1430s, his powers had swollen to an immensity that outraged any conception of a natural order. Whoever was scandalized by this outrage began to reconsider the devil, at first drawing on a concept from early classical natural philosophy that has been labelled "double determination" by G. E. R. Lloyd. ${ }^{4}$ Eventually, many thinkers concluded that it was superstitious to believe the devil had power over the natural order. This rethinking helped expand the concept of superstition beyond something specifically religious to a wider signification as the counterfoil to the new philosophy.

The Renaissance saw "magic" and "occult" as words contaminated with the negative qualities of superstition: a view held by many today, but with a change in definition. A heavily freighted concept, superstition in the Renaissance was linked so closely to the devil that its meaning depended on his stature. Few doubted his existence, but when the general belief in his material powers altered, then a change came to what "superstition" meant as well. In the mid-1500s, superstition equalled witchcraft, and the devil was lord of both; a century later, both witchcraft and the devil, or at least his physical agency,

1. John Henry, "The Fragmentation of Renaissance Occultism and the Decline of Magic," History of Science 46 (2008), pp. 1-48.

2. Stuart Clark, Thinking with Demons (Oxford: Clarendon, 1997), pp. 262-66, 304.

3. Keith Hutchison, "What Happened to Occult Qualities in the Renaissance?" Isis 73 (1982). Reprinted in The Scientific Enterprise in Early Modern Europe: Readings from Isis, ed. Peter Dear (Chicago: University of Chicago Press, 1997), pp. 86-106.

4. G. E. R. Lloyd, Magic, Reason and Experience: Studies in the Origin and Development of Greek Science (Cambridge: Cambridge University Press, 1979), pp. 31, 51. 
were viewed by those aligned to the new philosophy as prime examples of what superstition designated.

The devil had always been strongly associated with magic. ${ }^{5}$ Always an ambivalent term, ${ }^{6}$ magic came in two categories, licit and natural or illicit and demonic. The separation between the two was never clean, since a magician's apparent expertise in natural magic might rest on the cooperation of demons working unseen to make his incantations fruitful, perhaps without him even knowing. ${ }^{7}$ Although the church accepted natural magic, it tended to emphasize the demonic aspect, since the devil was the greatest of magicians. He could work with natural properties to bring about all possible effects, ${ }^{8}$ or at least to fool our senses into thinking that he had done so. Everyone acknowledged that Satan was God's creation, and could do nothing outside nature. ${ }^{9}$ But even within those bounds, his power was huge, and the witch hunt magnified it as never before. ${ }^{10}$

A symbolic dimension extended the devil's power even further. Bacon described his Great Instauration as the restoration of the powers mankind had lost in the Fall, and his descendants in the Royal Society accepted this as a founding myth. Satan was the agent of the Fall, identified with the serpent in the Garden, and thus associated with forbidden knowledge from the beginning. Lying like a dragon across the threshold of forbidden knowledge, he tempted people to cross that threshold, and tore them apart if they did. Augustine had condemned intellectual curiosity in the strongest terms, ${ }^{11}$ and these fears were much alive in the Renaissance, as the new myth of Doctor Faustus showed.

5. The Apocalyptic literature that so strongly influenced Christianity showed him as the lord of magic, teaching humanity forbidden arts or assisting Pharaoh's magicians in their contest with Moses. See James H. Charlesworth, ed., The Old Testament Pseudepigrapha (New York: Doubleday, 1983-85), "Book of Enoch," vol. 1, pp. 15-17, and “Book of Jubilees," vol. 2, p. 139.

6. See Naomi Janowitz, Magic in the Roman World: Pagans, Jews and Christians (London: Routledge, 2001), who makes the point that magic is commonly the term used to condemn someone else's religion.

7. Henry, pp. 15-16.

8. Clark, pp. 161-71, chapters 14, 15, passim.

9. Clark, pp. 170-71.

10. Jeffrey Burton Russell, Lucifer: The Devil in the Middle Ages (Ithaca: Cornell University Press, 1984), p. 301.

11. See William Eamon, Science and the Secrets of Nature: Books of Secrets in Medieval and Early Modern Culture (New Haven: Princeton University Press, 1994), pp. 59-63. 
The devil and his magic thus branched into a troika of terms that were broadly equivalent: superstition, idolatry, and vain observance. By 1400, all had become synonyms for witchcraft. ${ }^{12}$

Both Reformations, Protestant and Catholic, shared a common concern with reforming popular practice and belief. Above all, this meant cleaning away the superstition and popular magical practice that encrusted everyday life. ${ }^{13}$ Whereas the medieval church had tolerated much of this, the reforming energies of the era from 1400 to 1700 saw such practices as far from harmless: they were nothing less than idolatry, the greatest of sins.

This emphasis on idolatry marked a major shift in consciousness, which John Bossy characterizes as the move from a morality based on avoiding the seven deadly sins to one observing the Ten Commandments. ${ }^{14}$ A new theology ${ }^{15}$ emphasized God's absolute sovereignty, and with it a new and increasingly onerous conception of fundamental human sinfulness. These changes predated the Reformation and were shared by both main confessional streams. Whereas the old morality had emphasized sins against society, the new emphasized sins against God, and stressed how unknowable, terrifying, and unapproachable he was. Nothing angered him more than idolatry: his first two commandments were devoted to condemning it. And as God grew more terrifying, so did the devil. In the old morality he had been the enemy of sociability, comical as often as not, but the new conception set him up as God's rival, the goal of all idolatry, the titanic rebel angel whose greatest wish was to be worshipped himself. ${ }^{16}$

12. See Michael Bailey, Battling Demons: Witchcraft, Magic and Heresy in the Late Middle Ages (University Park, PA: University of Pennsylvania Press, 2003), pp. 130-38; Jean Gerson, De erroribus circa artem magicam, in Ouevres complètes (Paris / Tournai / Rome: Desclées et Cie, 1960), vol. 10, pp. 77-90; Alan C. Kors and Edward Peters, "Bernardino of Siena Preaches against Women Sorcerers," in Witchcraft in Europe 400-1700: A Documentary History, $2^{\text {nd }}$ edition (Philadelphia: University of Pennsylvania Press, 2001), ch. 24, pp. 133-37.

13. See John Bossy, Christianity in the West, 1400-1700 (Oxford and New York: Oxford University Press, 1985).

14. See John Bossy, "Moral Arithmetic: From Seven Sins to Ten Commandments," in Conscience and Casuistry in Early Modern Europe, ed. Edmund Leites (Cambridge: Cambridge University Press, 1988), pp. 214-34.

15. See Heiko Oberman, "Via Antiqua and Via Moderna: Late Medieval Prolegomena to Early Reformation Thought," in From Ockham to Wyclif, ed. Anne Hudson and Michael Wilks (Oxford: Blackwell / Ecclesiastical History Society, 1985), pp. 445-63.

16. Bossy, "Moral Arithmetic." 
The new emphasis on superstitious and magical practices was expressed by the University of Paris faculty of theology in 1398, in a ruling historians agree was foundational for the witch hunt. A key point of this ruling was that "every superstitious observance, the effect of which is not to be reasonably expected from God or nature," contained an "implicit pact" with demons and was therefore a "form of idolatry." ${ }^{17}$ If magic had been suspect before, it became doubly so as the gradual spread of the witch hunt in the fifteenth century increasingly emphasized its demonic side. ${ }^{18}$

Our discussion here centres on England, where the foundation of Reformation theology was Calvinist. ${ }^{19}$ Calvin presents the problem of superstition and idolatry with great logical clarity. In chapter 3 of the Institutes, he writes that "knowledge of God is naturally implanted in the human mind," and then immediately moves in chapter 4 to discuss "how this knowledge is either smothered or corrupted." He focuses principally on idolatry and superstition, using the words two and four times and exploring the concepts at length. He describes how people do not worship God as he is, but “....ce n'est pas luy qu'ils honnorent, mais en son lieu leurs songes et resveries" (in his place their own dreams and imaginings). While they intend their superstition to please God ("quand la superstition veut gratifier à Dieu"), they depart from him so that "il ne reste plus qu'une idole exécrable" (nothing remains but a disgusting idol). ${ }^{20}$

Calvin was only emphasizing the meanings that superstition and idolatry had always carried. Idolatry was the sin of sins in the Old Testament, and superstition was also an ancient term, a concept central to Roman religion. In their 1998 review of Roman religion, Beard et al. assert that religio and superstitio were opposite categories braided together into the Roman concept of religion

17. Translation is from Johann Weyer, Witches, Devils and Doctors in the Renaissance: De praestigiis daemonum, ed. George Mora, MD, and Benjamin Kohl, trans. John Shea (Binghamton, NY: Medieval and Renaissance Text Studies, 1991), pp. 576-80. This document is also reproduced in Kors and Peters, Witchcraft in Europe 400-1700, pp. 127-32, but their version unaccountably leaves out the key point quoted above. The Latin can be found in Gerson, vol. 10, p. 88: "Et intendimus esse pactum implicitum in omni observatione superstitiosa cujus effectus non debet a Deo vel natura rationalibiter exspectari."

18. John Henry makes this point. Henry, pp. 15-16.

19. Diarmaid MacCulloch, The Later Reformation in England, 1547-1603 (New York: St. Martin's Press, 1990), p. 77.

20. Jean Calvin, Institution de la Religion Chrétienne, critical edition, ed. Jean-Daniel Benoît (Paris: Librairie Philosophie, J. Vrin, 1957), vol. 1, ch. 3, 4, pp. 63-65. My translations. 
from the beginning, so interdependent that they are hard to define in isolation. ${ }^{21}$ Superstitio was both irregular religion and excessive religion, and by the early second century CE it had "begun to denote the religious practices of particular foreign peoples." This first meaning, of strange and contemptible foreign religion, remained with superstition thereafter, and we will call it the "A" meaning. Christianity gave the term a second major meaning when it took over the Roman world, and theologians like Lactantius began using superstitio to delineate the boundary between Christianity and paganism. ${ }^{22}$ Superstition equalled pagan religion which was by definition idolatry, the worship of false gods. ${ }^{23}$ Augustine equated superstition with idolatry and associated both with the deceptions of demons, along with the term "vain observance" (vana observatio or vanus/a).

This view of superstition as idolatry and then demonolatry remained central to Christianity, as the word was taken directly into English and all Romance languages. We will call this classic Christian signification the " $\mathrm{B}$ " meaning. The fury of religious controversy generated a third, "C" meaning for Protestants, who used superstition as the term for Catholic ritual and belief (Catholics retaliated by calling Protestantism heresy). This meaning was very strong among the English and the Scots, who both liked to see Catholicism as the enthronement of superstition.

Within the principal or "B" meaning, all reformers saw a strong equivalence between superstition and witchcraft, and this is the understanding that made witch-hunting respectable. ${ }^{24}$ Historians talk of two broad strands running through the hundreds of contemporary writings about witchcraft and witches; in 1972, Erik Midelfort referred to these as the "providential" and "persecuting" strains ${ }^{25}$ Most witch hunts were driven by the persecuting tradition, which

21. Mary Beard, John North, and Simon Price, Religions of Rome (Cambridge: Cambridge University Press, 1998), vol. 1, pp. 221, 228.

22. Both references from Arnaldo Momigliano, "Popular Religious Beliefs and the Late Roman Historians," in Popular Belief and Practice, ed. G. J. Cuming and Derek Bakan, Studies in Church History 8 (Cambridge: Cambridge University Press, 1972). The quotation can be found on p. 8 , and the Lactantius reference on p. 11.

23. Drawing on clear Old Testament authority, St. Paul had called the pagan gods "demons" (I Corinthians 10:20). I have used the Authorized Version for biblical quotations.

24. John Henry understands this point. Henry, pp. 15-16.

25. Erik Midelfort, Witch-Hunting in Southwestern Germany (Stanford: Stanford University Press, 1972), p. 63 ff. The position has been criticized by Stuart Clark as too simplistic, but is useful for at least 
emphasized the devil's direct agency and developed increasingly lurid accounts to describe it, but this was always a minority position. The providential view was the mainstream. Generally rather skeptical about the powers of witches, its central point was that the real danger of witchcraft was not the immediate harm it did, but how fear of witchcraft led people to doubt God's providence.

Both viewpoints asserted the existence of the devil and his concrete agency in the world, and both agreed that witchcraft was superstition and therefore at bottom was demonolatry. So strongly was this equivalence held that many writers in the providential tradition argued that "white" witches were worse than black, "cursing," witches: both relied on Satan, whether they knew it or not, but white witches were respected in their communities and thus much more likely to lead the innocent into deadly $\sin .^{26}$

The complete equivalence of superstition with witchcraft is demonstrated forcefully in a popular 1530 work, A Treatise Reproving All Superstitions and Forms of Witchcraft, by the Spanish theologian Pedro Ciruelo. Ciruelo provides a full catalogue of contemporary superstitious practices. Drawing on Augustine and Aquinas, he uses "witchcraft," "idolatry," "superstition," and "vain observance" interchangeably, ${ }^{27}$ emphasizing that all involve worship of the devil and treason to God, and are therefore the greatest of sins. ${ }^{28}$ The consequences were not just grave for the guilty, but for everyone, since those who employ superstitious practices "offend God in a grand manner and greatly incite his anger against those people and lands where such sins are tolerated and permitted .... In the end, they draw down the anger of God upon the nations, cities and villages where they are tolerated." ${ }^{29}$

Every "vanity" or "vain observance" was a magical operation, condemned by Ciruelo in terms drawn from Augustine and almost quoting the 1398 Paris decision:

differentiating extremes on a continuum.

26. See, for example, William Perkins, "A Discourse of the Damned Art of Witchcraft," in Courtenay Reformation Classics, Vol. III: William Perkins (Berkshire: Sutton Courtenay Press, 1970), pp. 596-97.

27. For examples, see Pedro Ciruelo, A Treatise Reproving All Superstitions and Forms of Witchcraft, trans. Eugene A. Maio and D’Orsay W. Pearson (London: Associated University Presses, 1977), pp. 58, 91.

28. Ciruelo, pp. 77, 57-58.

29. Ciruelo, p. 58. 
The rule is this: in every action which man performs to bring about some good or avoid some evil, if the things that he uses or the words that he employs possess neither natural nor supernatural power to bring about the desired effect, then that action is vain, superstitious, and diabolical; and the effect which is produced comes from the secret operation of the devil .... We call vain whatever cannot accomplish that for which it is employed. ${ }^{30}$

Ciruelo was writing in the theological mainstream, before the Reformation divided western Christianity, so comparison with Calvin shows us just how strongly superstition, idolatry, vain observance, and witchcraft were tied together, with the devil at the centre.

\section{Double determination: Wier and Gifford}

One of the most spectacular powers ascribed to witches was the ability to call up storms. ${ }^{31}$ Learned witch-hunters agreed that witches could do this, and differed from uneducated villagers only by insisting that a witch's spell had no causative power in itself, but took effect by calling up a demon who did the actual work. The Jesuit theologian Martín Del Rio stated, as a matter of simple fact, that demons worked at the behest of witches to "calm tempests, rouse thunder and lightning, hailstorms, showers of rain, or any other manifestations of the weather." ${ }^{32}$ Writing in 1599, Del Rio embodied the best academic thinking: his Investigations into Magic was reprinted frequently and became so authoritative that even Protestants cited it.

Del Rio was writing partly to refute the Dutch physician Johann Wier (or Weyer), whose earlier book On the Tricks of Demons, first issued in 1563 (in Latin), had caused a scandal as the first systematic attempt to refute witch beliefs. Wier had mounted an argument with two prongs. First, accused witches were lonely old women suffering from melancholy. Their confessions were

\section{Ciruelo, p. 94.}

31. See in particular Wolfgang Behringer, "Weather, Hunger and Fear: Origins of the European WitchHunt in Climate, Society and Mentality," reprinted in The Witchcraft Reader, ed. Darren Oldridge (New York and London: Routledge, 2002).

32. Martín Del Rio, Investigations into Magic, trans. and ed. P. G. Maxwell-Stuart (Manchester and New York: Manchester University Press, 2000), p. 84. 
delusional, and if the devil was actually involved, his activity was limited to convincing them of the reality of their imaginings. The second prong, which concerns us here, was that the devil had no power to carry out the will of witches. Wier specifically addressed the power to make storms, and here relied on the earliest classical writings to present a clear concept of an autonomous natural order in which the gods did not interfere. These are the Hippocratic writings of the early fifth century BCE, which the modern philosopher of science G. E. R. Lloyd sees as the foundation of the Greek concept of nature. ${ }^{33}$

Early modern Europe had inherited the classical conception of nature as the full domain of God's creation, but now the claims of witch-hunters had pushed forward a problem similar to that faced by the pre-Socratic Greeks, of keeping this natural order free from the capricious actions of superhuman beings. A devil who could make storms clearly mocked any meaningful natural order, no matter if he worked within nature. To address this problem, Wier turned to Hippocrates, whose work was on the curriculum in Renaissance medical schools and thus well known.

Hippocrates's presentation of a comprehensive natural order is most explicitly stated in his work "On the Sacred Disease." ${ }^{34}$ For Hippocrates, the natural order is itself divine, and it is universally and solely determined by natural causes. The gods may exist, but they are outside it and do not meddle in its regularity. If they did so meddle, their action would disrupt the chain of natural causes and thus be a supernatural event equivalent to what Renaissance thinkers would have called a "miracle" and assigned to God alone. Otherwise, the gods express their wills only by acting within and through natural events. Such an action by a god would add nothing to what was already purely natural and going to occur in any case. Lloyd's term for such an event (as mentioned earlier) is "doubly determined": "brought about both by gods and by natural causes, the former working through the latter." ${ }^{35}$

In insisting on the primacy of the natural order, Hippocrates particularly vituperates the magicians of his day, with their absurd claims to "draw down the moon, cause an eclipse of the sun, make storms and fine weather, rain and 
drought...." Such claims dishonoured the divinity of the natural order and were thus absurd, impious and "hateful to the gods."36

Seeking to limit the devil's agency, Wier drew on Hippocrates, finding inspiration in exactly the same place where Lloyd finds the strongest illustration of his thesis. In fact, Wier used the double determination argument. Needing to cast doubt on the devil's capacity to do anything so huge as cause a storm, Wier argued that Satan deceived a disturbed old woman into believing he acted at her request. Such trickery required the devil to understand nature, but implied no power to actually command it:

As soon as [Satan] foresees from the movement of the elements and the course of nature that the air will change and there will be storms (which he sees more quickly and easily than men can) ... he agitates the minds of these poor women and fills them with various images and suggestions. ${ }^{37}$

So the old woman enacted a magical ritual, and when a storm subsequently arose, she believed she had caused it. Such a storm would not be doubly determined, strictly speaking, as the devil's power has been restricted to appearing to act in and through a natural event; but the argument is a version of double determination, applying the same concept in a new setting.

Four of Wier's citations of Hippocrates ${ }^{38}$ are from "On the Sacred Disease," and one quotes in full the passage given by Lloyd in illustration of his thesis. ${ }^{39}$ Wier brings up this same passage a second time, and exactly where he most disputes the devil's power. Hippocrates had written that the absurd claims of magicians to "make storms and fine weather" were "hateful to the gods" because they pretended that "the divine power [could be] overcome and forced into subjection by the human will." ${ }^{\prime 0}$ Wier echoes this exactly. After suggesting that Satan only pretends to cause a storm at the witch's command, he goes on to write that "if tempest, rains, hail, and lightning served the will of these

36. Hippocrates, Hippocratic Writings, ed. and trans. G. E. R. Lloyd (Harmondsworth: Penguin, 1978), p. 239.

37. Weyer, p. 214.

38. Weyer, pp. 158-60, 169-70, 214-15, 344, 355, 462, 500, 544.

39. Weyer, pp. 158-60.

40. Hippocrates, p. 239. 
women ... divine power would be surpassed and overcome by human will, 'as though reduced to servitude,' as Hippocrates has so effectively put it." Instead, Wier concludes, "No person of sound mind should believe that the elements obey the futile actions of poor crazy women," and a little later he writes that it is an "unspeakable form of idolatry where people attribute to Lamiae [witches] that which pertains to the Divine Majesty alone - the voluntary stirring of storms and inciting of hail." ${ }^{41}$ The divinity of God's natural order requires that its regularity be protected from the meddling of the devil.

In the Greek version of double determination, gods expresses their will through a natural storm. Wier applies this idea to undercut the devil's power to achieve major effects in the natural order, reducing his power to pretending to act. His version moves the burden of idolatry and superstition from the witches to those who believe witchcraft is possible. This began a significant change in the meaning of superstition.

Wier further concludes, in one of the last chapters of his book, that demonic action in nature is impossible, for the following reasons. Demons can act only with God's permission, and therefore rely on God's will, which is unknowable to mortals or demons. Consequently, it is beyond the power of demons to know whether their actions will be effective or not, and so even if demons exist and even if they attempt to act, the result of either a witch's spell or a demon's intervention "must therefore be a chance happening, if you will." ${ }^{42}$ As such, it is no different from any other chance happening, and therefore fully within the realm of the natural. Double determination could go no further.

At this point we come to the importance of spiritualism. Hans de Waardt has shown that Wier was not only fully conversant with spiritualist ideas, he actively expressed them in his work and almost certainly corresponded personally with one of their principal leaders, David Joris. ${ }^{43}$ Spiritualists held the belief that the devil was not a real being and that demons were not external forces, but that both were only symbols or expressions of the sinful nature of men,

41. Weyer, pp. 214-17.

42. Weyer, p. 563.

43. Hans de Waardt, "Witchcraft, Spiritualism and Medicine: The Religious Convictions of Johann Wier," Sixteenth Century Journal 42, no. 2 (2011), pp. 369-91. 
the interior urges of the "old Adam." Joris's opinion on the devil was clearly expressed as early as $1541,{ }^{44}$ and would certainly have been known to Wier.

Since Wier makes no mention of demonic agency in his specialist medical writings, De Waardt argues that he went against his own beliefs in adapting On the Tricks of Demons to fit a wide audience, and that the two points on which modern readers often find him lacking, the continuing if weak agency of demons and the intellectual nullity of women ${ }^{45}$ were both rhetorical positions, adopted to fit his greater goal of influencing public policy. ${ }^{46}$

If De Waardt is right, we can suggest that Wier perhaps disbelieved in the devil's agency altogether, but was unable to say so because he wanted to write a mainstream book that would reach as many people was possible, and which was already controversial enough. To say that the devil couldn't influence reality at all would have been to clearly identify himself with outcasts like Joris, whose opinion on the devil's non-existence was well known. ${ }^{47}$ Given this, Wier likely picked up the double determination line of reasoning because it was a middle ground, and because it had the authority of its classical provenance. All his readers would have been able to look it up, and all would have accepted the authority of Hippocrates.

This was a successful calculation, as is shown by its influence on George Gifford, an English Protestant parson who also wrote against witch-hunting. Gifford was no spiritualist sympathizer-he preached fiercely against nonconforming Christians and in particular the spiritualists ${ }^{48}$ - but he was also appalled by the witch hunts he had personally observed. Gifford is a good example of the providential school; he accepted witchcraft as a fact, but saw its real harm in the fear people had of it. His main concern was pastoral, that his parishioners jeopardized their souls by seeking protection from "white witches" against black witchcraft. Wanting to convince them to rely on God alone, Gifford argued there was no real cause to fear witchcraft.

44. Gary K. Waite, "Man is a Devil to Himself: David Joris and the Rise of a Sceptical Tradition towards the Devil in the Early Modern Netherlands, 1540-1600," Dutch Review of Church History 75, no. 1 (1995), pp. 1-30.

45. Clark, pp. 117-18, 162, 198-203.

46. De Waardt, pp. 387, 390-91.

47. Waite, “Man is a Devil," pp. 20-25.

48. Gary K. Waite, Heresy, Magic and Witchcraft in Early Modern Europe (Basingstoke: Palgrave Macmillan, 2003), p. 192. 
For Gifford, Wier was too far out. Gifford claimed to be writing against two extremes: those who uncritically accepted the power of witches and devils, writers such as Del Rio; and those who held that all witchcraft was "mere cosenage, or poisoning." "Cosenage" (cheating or fakery) was the explanation given by his scandalous Essex neighbour Reginald Scot, discussed below; while "poisoning" referred to Wier, who had stressed it as the only real power witches possessed. Gifford was aware of the melancholy argument, but did not stress it; his concern was focused on denying the devil's power to carry out the will of witches. Here he picked up the double determination argument and took it further than Wier, so that by his widely read Dialogue concerning Witches and Witchcraft (1593), Gifford's position had evolved to suggest that the devil had no power beyond deceiving the thoughts of people.

The Dialogue is a conversation contrasting possible points of view about witchcraft. The naïve view is presented by Samuel, a simple countryman who describes several recent cases. In one, "Old mother W. of Great T" confessed to having killed a man, using witchcraft to inflict a fatal illness on him. For this task she had employed her familiar spirit, which bore the shape of a weasel and lived in a pot of wool under her bed until she fed it with the blood of a cock and sent it forth to attack the man.

Gifford expresses his own opinion of this story (very likely based on real testimony) through the pious and educated Daniel, who points out that devils are spirits with no shape of their own, so one could only pretend to be under an old woman's control. "Can you be so simple as to imagine that the divell lieth in a pot of wooll, soft and warme, and stirreth not, but when he is hired and sent?"50 Daniel turns the woman's familiar into the local manifestation of a great abstract Devil, whose being is purely intellectual. It is this intellectual devil who kindled the witch's anger and led her to believe she had the power to command him.

Daniel then goes further. Even if "old mother W." believed she had killed the man by witchcraft, and the devil had encouraged her so to believe, and the man had in fact died, was the actual harm caused by the devil?

49. George Gifford, A Discourse of the Subtill Practises of Deuilles by Witches and Sorcerors, facsimile of the 1587 edition (Amsterdam and Norwood, NJ: Theatrum Orbis Terrarum / Walter J. Johnson, 1977), unpaginated, ch. 1.

50. George Gifford, "A Dialogue Concerning Witches and Witchcraft," in The Witchcraft Papers: Contemporary Records of the Witchcraft Hysteria in Essex, 1560-1700, ed. Peter Haining (London: Robert Hale, 1974), pp. 27-28. 
There be naturall causes of tortures and grief, of lameness, and of death in the bodies of man and of beastes, which lie so hid and secret, that the learnedest physitians cannot espie them, but the divell seeth them, and can conjecture very neare the time when they will take effect. Then doeth he plie it, to bring the matter about that it may seem he did it. ${ }^{51}$

The devil saw that the man was about to become sick, and used his power to stir up rage in the witch's heart, to make her believe she had power to cause sickness. Satan's magical power shrinks to nothing more than the ability to foresee the course of natural causes. Gifford takes Wier's version of double determination further. He concedes it is possible "that the Lord had given Satan power to plague the man in his bodie ... but it is most like that his body did languish and pine of naturall causes, which the divell did know, and so would be sent, and seeme to do all, when as indeed he had no power to touch him." 52 Even if the devil was involved, he could not influence the natural causes already operative. Seeking to argue his parishioners out of their fear of witchcraft, Gifford has argued away the devil's power to act in the natural world.

More mainstream than Wier, Gifford's position was attractive to many of the clergy. It was uneasily harmonized with the belief that witchcraft was possible, since however much he wanted to restrict the devil's agency, Gifford still believed Satan was concrete enough to physically appear and perhaps work some material effects.

\section{Scot: new uses of superstition}

The war on superstition forms the entire background of Gifford's work, even if he little mentions the word. Superstition is even more central to Wier. ${ }^{53} \mathrm{His}$ book 5 is devoted to a condemnation of superstitious cures, and the word "superstition" appears often. ${ }^{54}$ Moreover, Wier concludes his book by printing

51. Gifford, Dialogue, p. 42.

52. Gifford, Dialogue, pp. 44-45.

53. De Waardt writes that Wier stated his original intention was "to write a book that will purge the medical profession of superstition" (De Waardt, p. 389), but I have been unable to find his reference in any text available to me, including the online facsimile of the first edition accessible at www.books. google.com.

54. See Weyer, pp. 361, 372, 373, 386, 387. 
the full text of the 1398 Paris pronouncement against magic and superstition..$^{55}$ Given the climate he was writing in, Wier could not have more clearly stated that the real superstition was to believe in the possibility of witchcraft. If the false healers and enchanters whom he describes at length in the other parts of his book are given over to superstition, equally so are those who believe in the efficacy of their works, and most of all, so are those foolish enough to believe the devil is involved.

Wier's open skepticism about witches and the devil was taken up by Reginald Scot. Writing in a less dangerous environment than Wier, Scot had less need to dissemble what he actually thought. His skepticism, on both the devil and the occult, is remarkably thoroughgoing, but superstition is his principal target. Scot uses the word 57 times, ${ }^{56}$ and always with a signification that approaches our modern meaning.

Scot categorically denied that the devil could take physical form and manipulate natural phenomena. In the appendix to his 1584 Discoverie of Witchcraft, the "Discourse upon divels and spirits," Scot states that spirits are utterly separated from physical reality and cannot affect it. Only "blockheads" think otherwise: "a spirit is no sooner spoken of, but immediately they think of a blacke man with cloven feet, a paire of hornes, clawes, and eies as broad as a bason" [eyes as broad as a basin]. Such beliefs, "being contrarie to nature, probabilitie and reason, are void of truth or possibilitie." ${ }^{27}$

Yet Scot had no doubt of the devil's ultimate reality: "I denie not therefore that there are spirits and divels, of such substances as it hath pleased GOD to create them." ${ }^{38}$ But since actual spirit is a subtle thing, "such that no man can by learning define, nor by wisedome search out," spiritual entities cannot present themselves in physical form. ${ }^{59}$

55. Weyer, pp. 576-80.

56. Based on manual count in Reginald Scot, The Discoverie of Witchcraft, intro. Montague Summers (New York: Dover, 1972). Cited hereafter as "Scot (1)." I have used the Summers edition because it is widely available.

57. Reginald Scot, The Discoverie of Witchcraft, facsimile of the 1584 London edition (Amsterdam and New York: Theatrum Orbis Terrarum, 1971), pp. 509, 507. Cited hereafter as "Scot (2)."

58. $\operatorname{Scot}(2)$, p. 510.

59. Recently it has been argued that Scot too was a secret spiritualist; see David Wootton, "Reginald Scot / Abraham Fleming / The Family of Love," in Languages of Witchcraft: Narrative, Ideology and Meaning in Early Modern Culture, ed. Stuart Clark (Basingstoke: Macmillan Press, 2001), pp. 119-38. A more 
The providential tradition equated superstition with witchcraft. Gifford suggested, and Wier stated, that the real superstition was to believe in witchcraft at all, and Scot wholeheartedly agrees. His emphasis is reflected in his use of a new and more general meaning for "superstition," ${ }^{30}$ bringing the term close to its modern signification, "1. credulity regarding the supernatural; 2. an irrational fear of the unknown or mysterious." ${ }^{61}$ This new meaning absorbed our earlier "A" (bizarre foreign beliefs) and "C" (anti-Catholic) significations, while rejecting the precise religious " $\mathrm{B}$ " meaning as too narrow. We will call it the "D" signification.

This evolution is fully evident in Scot, who also uses "idolatry" frequently. Of the 57 uses of "superstition" or "superstitious" in his book, ${ }^{62}$ nothing but the modern " $\mathrm{D}$ " meaning can be identified in 48: for example, "foolish superstition and credulity," "because old women have such charmes and superstitious meanes ...", "[from melancholie] proceed feares, cogitations, superstitions ...."63 Scot even calls the type " $\mathrm{B}$ " theological meaning of superstition " $a$ ridiculous definition of superstition." 64

Uses that contain the type "C" anti-Catholic shading reinforce the point. Scot certainly shared in the general censure of "the pope's absurd religion," but he calls it "superstitious" precisely because he sees it as fomenting superstition in the modern sense, partly by fostering witch-hunting: "patrone" of all idols, the pope "canonizeth the rich for saints, and burneth the poor for witches." 65

recent biographer disagrees, but does argue for the centrality of his theological concerns; see Philip C. Almond, England's First Demonologist: Reginald Scot (London and New York: Taurus \& Co., 2011), pp. $187-89$.

60. We can trace this change in other writings of the time. Shakespeare uses "superstition" nine times, and always in the modern sense. See Marvin Spevack, The Harvard Concordance to Shakespeare, (Cambridge, MA: Belknap Press of Harvard University Press, 1973). For example, Cassius (Julius Caesar, 1599) contemptuously remarks that because Caesar "is superstitious grown of late," he may heed his wife's prophetic dream to stay home on the Ides of March (2.1.195).

61. The Concise Oxford Dictionary (Oxford: Clarendon Press, 1990).

62. Scot (1). For all instances, see pp. 4, 9, 17 (3x), 20, 27, 33, 34, 42, 65, 96, 97, 108, 109 (4x), 111 (2x), $112,115(2 x), 116(3 x), 117$ (2x), 118 (2x), 121, 122, 123, 136, 137, 141, 146, 152, 153, 160, 166, 167, 174, $176,211,251,255(5 x), 266,270,271,272,281$ (3x).

63. Scot (1), pp. 146, 160,33; Scot (2), pp. 257, 283, 57-58.

64. $S \cot (1)$, p. 255; Scot (2), pp. 438-39.

65. Scot (2), pp. 521-22. 
The infamous Malleus maleficarum is attacked as nothing but superstition, as when Scot quotes its "monkish" authors on why a witch must be led backwards when she is brought before a judge:

Item, she must come to hir arreignement backward, to wit, with hir taile to the judges face, who must make many crosses, at the time of hir approaching the barre. And least we should condemn that for superstition, [the authors of the Malleus] prevent us with a figure, and tell us, that the same superstition may not seeme superstitious unto us. ${ }^{66}$

He is accusing the authors of the Malleus of propagating superstition in our modern understanding of the word. Later he gives his own and quite modern definition: superstition is that which makes us "so fond [foolish], mistrustfull \& credulous, that we fear more the fables of Robin good fellow; astrologers \& witches, \& believe more the things that are not, than the things that are." ${ }^{67}$ The cause is melancholy, "from whence proceed feares, cogitations, superstitions"; or ignorance, such as among those who be "poore, sullen, superstitious, and papists ...." ${ }^{68}$ Superstition is based on fancy and fearfulness only, and opposes "the things that are." In building his argument, Scot took an experimental approach; he rejected the category of the preternatural and disallowed occult qualities, ${ }^{69}$ which he wished "to accommodate ... within the domain of the knowable."70

\section{Bacon: superstition, idolatry, and vana}

Francis Bacon was not tempted to believe in the physical power of Satan, and so feels no need to refute it or even refer to it, although his work is replete with the language of witchcraft and enchantment and contains many figurative

66. Scot (1), p. 17; Scot (2), p. 30. The passage cited from the Malleus is found in Malleus maleficarum, trans. Christopher S. MacKay (Cambridge: Cambridge University Press, 2006), vol. 2, p. 504. The authors do in that place defend themselves against being thought superstitious, and use the term vana: "It is always lawful to smash vanities with vanities" / "vana vanis contundere" (vol. 1, p. 622).

67. $\operatorname{Scot}(1)$, p. $121 ; \operatorname{Scot}(2)$, p. 212.

68. Scot (1), pp. 33, 4; Scot (2), pp. 57-58, 7 .

69. See notes 2 (Clark) and 3 (Hutchison).

70. Almond, pp. 164-66. 
references to the devil. ${ }^{71}$ No one that I know of has linked Bacon with spiritualism, but spiritualist themes appear in his work, including his belief in the unity of Christendom and his call for a renovation of God's creation. And like the spiritualists, Bacon accepted the devil as a symbol, and a profoundly important one. He was writing at a time when the devil and his power was a constant topic of heated debate. For several years after 1599, England saw a major public controversy over the reality of demonic possession, with the Anglican bishops asserting its nullity through the writings of Samuel Harsnett, and the Puritans furiously insisting on the devil's reality and the need for Puritan holiness to deal with him. ${ }^{72}$ This controversy, which peaked in 1603 with Harsnett's second book A Declaration of Egregious Popish Impostures, followed a similar controversy in France, led by the ultra-Catholics and inspired by theologians like Del Rio. ${ }^{73}$ Harsnett's Declaration was so widely circulated that references found their way into Shakespeare's King Lear. ${ }^{74}$

It is beyond doubt that Bacon was exceedingly exercised by the devil's symbolic power, and centrally concerned with the troika of superstition, idolatry, and vana, which together described the "enchanted glass" of the human mind in its fallen state. His new method was presented as the means to overcome these and to return us to our original state before the Fall. This new way of knowledge was not forbidden, would be neither superstitious nor idolatrous, and would reverse the influence of the devil.

71. See, for example, "The Charge Touching Duels" in Francis Bacon: A Critical Edition of the Major Works, ed. Brian Vickers, The Oxford Authors (New York and Oxford: Oxford University Press, 1996), pp. 104-14. When Bacon describes the effects of upbringing and education on people's thinking, in his unpublished 1607 essay "Cogitata et Visa", he writes: "Every individual, in consequence of his education, interests, and constitution is attended by a delusive power, his own familiar demon, which mocks his mind and troubles it with various unsubstantial specters," quoted in Benjamin Farrington, The Philosophy of Francis Bacon: An Essay on Its Development from 1603 to 1609 with New Translations of Fundamental Texts (Liverpool: Liverpool University Press, 1964), pp. 88-89.

72. See Daniel P. Walker, Unclean Spirits: Possession and Exorcism in France and England in the Late Sixteenth and Early Seventeenth Centuries (London: Scholar Press, 1982).

73. See Jonathan A. Pearl, The Crime of Crimes (Waterloo: Wilfrid Laurier Press, 1999).

74. King Lear, 3.4. William Shakespeare, The Complete Works, general editor Alfred Harbage (New York: Viking, 1977). 
Bacon's unique "Confession of Faith"75 was likely written around 1603, ${ }^{76}$ when the Harsnett controversy was at its height. Here Bacon explicitly sets forth his view of the devil. He was "the first defected creature, and fell of malice and not by temptation," and then tempted us to fall. Adam fell when he preferred the light of his own reason to God's word, so that "death and vanity entered ... and the image of God in man was defaced." This devil is a spirit, as is the "soul of man," and "the ways and proceedings of God with spirits are not included in nature." This is possible because spirits were created before heaven and earth, while "the soul of man was not produced by heaven or earth, but was breathed immediately from God." Therefore, both are outside nature altogether. ${ }^{77}$

Bacon repeats the story in the unpublished Valerius Terminus, positively dated to 1603 and the earliest presentation of the Great Instauration. Whereas Satan fell through lust for power, Adam fell through lust for knowledge. ${ }^{78}$ With the devil's symbolic power and the ambivalent nature of knowledge at the heart of our beginnings, Bacon needed to assert that our love for knowledge remains good. He does so by insisting that all would be well as long as we restricted ourselves to the book of nature in all charity: "in pursuit towards the similitude of God's goodness or love neither man nor spirit ever hath transgressed, or shall transgress." Bacon reiterates the same point a decade later in the 1612 essay "Of Goodness and Goodness of Nature"; $;$ he is reassuring the reader, and perhaps even himself, that the devil has no power over those who stay within the boundaries God permits.

This thought is clearly essential to Bacon, since he addresses it very directly at the end of the preface to the Great Instauration, where the need for charity is again linked to Satan and the Fall: "We pray that when we have extracted from knowledge the poison infused by the serpent which swells and inflates the human mind, we may not be too wise with too high or too great a wisdom, but may cultivate the truth in all charity." He stresses that "inquiry into nature is [not] forbidden by an interdict," and repeats that if the angels fells through

75. Vickers, ed., pp. 107-12.

76. Vickers, ed., p. 560.

77. Vickers, ed. pp. 109, 108.

78. Francis Bacon, The Works of Francis Bacon. 12 vols., collected and ed. James Spedding, Robert Leslie Ellis, and Douglas Denon Heath (London: Longmans, 1857-69), vol. 3, pp. 217, 219. The Works is cited hereafter as "Bacon CW." See also Vickers, ed. p. 109.

79. Vickers, ed., p. 363. 
lust for power and man through lust for knowledge, "charity knows no bounds, and has never brought angel or man into danger." ${ }^{80}$ Beyond doubt, Bacon very seriously considered Satan's symbolic power as guardian of the forbidden.

The "poison infused by the serpent" is both pride, the manifest meaning, and our tendency to superstition and idolatry, for "the mind of man is far from the nature of a clear and equal glass, wherein the beams of things should reflect according to their true incidence; nay, it is rather like an enchanted glass, full of superstition and imposture." 1 This is because of "the idols and false notions which are now in possession of human understanding, and have taken deep root therein." 82

Bacon fully accepts the new meaning of superstition. He connects it directly to idolatry and then makes them the fundamental failings of the human mind since the Fall, failings which in his view can only be overcome by a collective pursuit of knowledge assisted by "machines." ${ }^{83}$ All around him, men preached that religion must be cleansed of superstition, idolatry, and vain observance. And so, Bacon tells us in the Novum Organum that he is "diligently, strictly and even religiously ... laying the foundations in the human intellect of a holy temple on the model of the world." ${ }^{84}$ Solomon's temple was of course the original for this image, the place of true worship and furthest thing from idolatry.

Bacon underlines the notion that superstition and idolatry are the fundamental failings of our minds in his choice of the term instauratio magna to describe the restoration of those powers we lost in the Fall. Instauratio is translated "renewal," but there are other Latin words with that meaning, and no Latin dictionary lists instauratio as the first. However, instauratio was like

80. Francis Bacon, The New Organon, ed. Lisa Jardine and Michael Silverthorne, Cambridge Texts in the History of Philosophy (Cambridge: Cambridge University Press, 2000), pp. 12-13. Cited hereafter as "Bacon NO."

81. Vickers, ed., p. 227; Bacon CW, vol. 3, pp. 394-95.

82. Bacon $C W$, vol. 4, p. 53. I prefer Spedding's translation to the more recent translation by Jardine and Silverthorne, which runs: "The illusions [their italics; Bacon's text is idola] and false notions which have got a hold on men's intellects in the past and are now profoundly rooted in them." Bacon, NO, p. 40.

83. Bacon, NO, pp. 13, 28-29.

84. Bacon, NO, pp. 91, 92. Both these insights derive from the discussion in John Channing Briggs, "Bacon's Science and Religion," in The Cambridge Companion to Bacon, ed. Markku Peltonen (Cambridge: Cambridge University Press, 1996), p. 176. 
superstitio in being originally a term from Roman religious practice, used as such in the sources Bacon read often and quotes much: Livy, Virgil, Tacitus, Pliny ${ }^{85}$ Roman religion laid great emphasis on precision. When an animal was sacrificed, the god's acceptance of the rite was signified by the appearance of the entrails. If any abnormality was seen, or if there had been an unlucky sound during the sacrifice, the rite had to be repeated from the beginning with a new animal. The term for this repetition was instaurare (verb), instauratio (noun). ${ }^{86}$ If the root meaning of superstitio was "incorrect worship," the root meaning of instauratio was "corrected worship." Bacon intended instauratio to imply the overcoming of superstition and idolatry.

In his 1612 essay "Of Superstition," Bacon states what he will develop at more length in Novum Organum, that at bottom superstition is the practice of rationalizing erroneous belief, where "arguments are fitted to practice, in reverse order." He chooses an illustrative example that compares the use of scholastic theology to preserve the erroneous practice of the medieval church with the creation of eccentrics and epicycles to "save the phaenomena" in the Ptolemaic system. ${ }^{87}$ Religious superstition, both the classical meaning and the type "C" anti-Catholic meaning, is directly compared with a "scientific" example of superstition.

Bacon's discussion of superstition and idolatry arises most fully in his famous discussion of the idols of the mind in the Novum Organum. He writes idola, which Lisa Jardine and Michael Silverthorne argue is better rendered by "illusions," ${ }^{88}$ although idolum/idola means "idol." It is true that Bacon's usage is not rigorously consistent: in The Advancement of Learning he writes "fallacies" in a place where in the Latin De augmentis he will use idola. ${ }^{89}$ Another commentator, Daniel Coquillette, suggests that Bacon's meaning is not the word's conventional meaning, but rather the usage of Democritus, the philosopher

85. See Charlton Lewis and Charles Short, A Latin Dictionary (Oxford: Clarendon, 1879), s.v. "instaurare." 86. John Scheid, "Sacrifices for Gods and Ancestors," in A Companion to Roman Religion, ed. Jorg Rupke (Oxford: Blackwell, 2007), p. 266; W. Warde Fowler, The Religious Experience of the Roman People (London: Macmillan, 1911), pp. 180, 190.

87. Vickers, ed., p. 373.

88. Bacon, NO, n. 18.

89. Vickers, ed., pp. 226-28. The word "idol" does not appear in this passage, even though editor Brian Vickers has given it that heading in the index. It does appear, however, in the Latin heading to the passage where Bacon discusses the failings of language (Vickers, ed., p. 228). 
who in Bacon's words "penetrated more deeply into nature than the others." 90 But these are distinctions without a difference. By eidola Democritus meant sensory images, which are all we can know and which forever block the way to things as they truly are. ${ }^{11}$ In Bacon's day theologians preached that idolatry did exactly that, misleading the minds of men with false sensory images that led to false understandings and a false knowledge of God. Calvin had seen superstition and idolatry as fundamental attributes of the human mind after the Fall, and the terms were constantly employed in Bacon's day to describe any attempt to adorn God's word with images or ceremony. It is not possible that Bacon could use the word "idol" without being sensitive to its common use in the world around him. In any case, while Bacon's fullest and most famous discussion of the idols is found in the Novum Organum, he raises the image for the first time in an English work, Valerius Terminus, and here he uses the word "idol." 92

Most general are the idols of the tribe. These are the fatal structures of our minds, inclined to superstition and idolatry. The method of the mind and the pattern of every superstition are the same. Imposing a false pattern on reality, the mind "invents parallels and correspondences and non-existent connections.... Once a man's understanding has settled on something ... it draws everything else also to support and agree with it." Having drawn the parallel, Bacon explicitly finds everyday superstition to be a good example of what he means: "The same method is found perhaps in every superstition, like astrology, dreams, omens, divine judgements and so on: people who take pleasure in such vanities notice the results when they are fulfilled, but ignore and overlook them when they fail." The predisposition to idolatry arises because the human understanding is most affected by things that "fill and expand the imagination," in exactly the same way that people prefer to create an idol of God from their own imagination rather than continue to seek Him as He is. Tired of the long journey to fact, the human mind looks for things it can recognize, so that "it falls back on things that are more familiar, namely final causes, which are

90. Bacon NO, pp. 45-46. See also Daniel Coquillette, Francis Bacon (Stanford: Stanford University Press, 1992), p. 228.

91. See John Mansley Robinson, An Introduction to Early Greek Philosophy (Boston: Houghton Mifflin, 1968), pp. 201-06.

92. Bacon $C W$, vol. 3, pp. 241-45. 
plainly derived from the nature of man rather than of the universe ...."93 Bacon takes the religious conception of idolatry and widens it to make it the basis of our everyday consciousness.

Discussion of the other three idols draws out further evidence that idolatry and superstition are the fundamental failing of the human mind. Idols of the cave are the illusions of the individual man, where knowledge is distorted to fit pre-existing belief; idols of the marketplace are the distortions imposed by language, where words create conceptual categories with no foundation in fact; and idols of the theatre are specific theories, built on the same desire to generalize widely on a narrow basis.

Worst of all is the superstitious kind of theory, which Bacon calls the "apotheosis of error," a disease of the intellect equivalent to "seeking the dead among the living" (Bacon's italics). This phrase refers to the origin of idolatry. Bacon identified himself with "Salomon," and the apocryphal "Wisdom of Solomon" gives a powerful account of the origins of idolatry that can be exactly summarized as "seeking the dead among the living." The story tells how a father's grief for his dead son leads first to sacrifices to the dead and then to the making of idols. ${ }^{94}$ As people are led forward into "superstition" they eventually reach the point of slaying their own children in sacrifices, ${ }^{95}$ and the conclusion is that "the worshipping of idols not to be named is the beginning, the cause, and the end, of all evil." ${ }^{16}$ Bacon had read this discussion of idolatry in the "Wisdom," as he quotes it in his 1622 "Advertisement Touching an Holy War."

Bacon does not neglect the third word in the troika, vain observance or vanus/vana. It is the object in a passage from Livy that he quotes at pivotal points in four writings from across his career, from the 1603 Valerius Terminus to the 1620 Novum Organum. The full quotation is "nil aliud quam bene ausus

\section{Bacon NO, p. 44.}

94. I first encountered this reference and thought in David Bakan, Disease, Pain and Sacrifice (Chicago: University of Chicago Press, 1968), and gratefully acknowledge my debt to him.

95. "Superstition" appears in the AV translation. Infant sacrifice, actually practised by the ancient Phoenicians and Canaanites, was always the biblical archetype of idolatry. See Serge Lancel, Carthage: A History, trans. Antonia Nevill (Oxford: Blackwell, 1995), pp. 227-56; James Rives, "Human Sacrifice among Pagans and Christians," The Journal of Roman Studies 85 (1995), pp. 65-85.

96. Wisdom of Solomon, 14:15-27.

97. Bacon $C W$, vol. 7, p. 22: "And, as I noteth, the Book of Wisdom noteth degrees of idolatry." The verse to which he is referring is Wisdom of Solomon 15:18. 
est vana contemnere" (That he simply had the courage to despise vanities). ${ }^{98}$ With so much emphasis placed by Bacon on this thought, it is worth noting its context in Livy. It occurs in a long rhetorical excursus where Livy unfavourably compares the deeds of Alexander with those of the Roman Republic. Livy's point is that Alexander's successes were based on his courage in despising vanities -in being unimpressed by the huge but weak armies he faced. The Romans, by contrast, built their empire by solid and lasting achievement. Bacon uses the quote as a metaphor to disparage the weakness of the philosophies he is overturning, saying that with systematic application of his method we could achieve real knowledge, just as the real achievement of the Roman Republic far outperformed Alexander's flashy career. This quote meant a lot to Bacon, as he says in one place, in his most dramatic work, "And we think that the same will be said of us." 99

Examples could be multiplied from Bacon's work far beyond what we have space for here. With so many references to superstition, idolatry, and vana, we cannot doubt that Bacon was exactly aware of the religious roots and meanings of these concepts, and employed them in a new way, to argue that his method would overthrow the superstition that had clouded our minds since the Fall. In one of his unpublished works, Bacon wrote that "next to the word of God Natural Philosophy is the most certain cure for superstition and the most approved nutriment of faith," and he repeats the thought in the Novum Organum. ${ }^{100}$ Clearly he saw the thing we call "science" in religious terms, in fact as a further and more perfect reformation of religion that took the fight against superstition to the universal level. Superstition and idolatry defined our fallen condition, and the new philosophy was their antonym.

And how does this touch on the devil? Superstition and idolatry are the "poison infused by the serpent," the failings of the human mind in its fallen state, and their overcoming through a new philosophy will lead to a new beginning, nothing less than the restoration of the powers that we lost in the Fall-the powers that Satan seduced us from. This overcoming cannot be

98. The references in Bacon are: Valerius Terminus (1603) in Bacon CW, vol. 3, p. 224; The Advancement of Learning (1605) in Vickers, ed., p. 145; "Redargutio philosophiarum" (1608) in Farrington; Novum Organum (1620) (Bacon NO, pp. 79-80). The reference to Livy is found in Livy, Rome and Italy, translated and annotated by Betty Radice (Harmondsworth, Middlesex, England: Penguin, 1982), p. 244.

99. Farrington, pp. 131-33 ("Redargutio philosophiarum”).

100. Farrington, p. 78 (“Cogitata et Visa”); Bacon NO, p. 75. 
achieved by individual effort, but requires a sustained collaborative approach, for which Bacon used mechanical models and illustrations. His approach was, we might say, a "scientific" solution to the spiritual problem of overcoming "the old Adam," an overcoming that the spiritualists equated with overcoming the devil. ${ }^{101}$

\section{The Royal Society's experimental approach}

The symbolic overcoming of the devil, and with it the overcoming of superstition and idolatry, were clearly understood and explicitly celebrated by Bacon's followers in the Royal Society. Thomas Sprat's 1667 official History of the Royal Society proclaimed the new philosophy as a new mode of religion, capable of justifying God and defending his church from all enemies. ${ }^{102}$ Along the way, it explicitly celebrated the Experimental Philosophy's triumph over the devil's symbolic power as the guardian of forbidden knowledge. We said earlier that the devil lay across the threshold of knowledge, and Sprat uses such images openly, writing that those who want to make progress in the new philosophy must labour to "devest themselves of many vain conceptions, and overcome a thousand false Images, which lye like Monsters in their way, before they can get as far as this." He sees the Church of England and the Experimental Philosophy as mother and child, working together to clear the land of monsters and sweep away all "the terrors and misapprehensions which commonly confound weaker minds, and make mens hearts to fail and boggle at Trifles." ${ }^{103}$ At the crest of his argument, Sprat describes how the Experimental Philosophy has liberated humanity from fear, overturning the false world of enchantments, fears, and spirits that oppressed all earlier generations:

[In former days], an infinit number of Fairies haunted every house; all Churches were fill'd with Apparitions; men began to be frighted from their Cradles, which fright continu'd to their Graves ...

101. See Waite, "Man is a Devil," passim.

102. Like Harsnett, Sprat ended up an Anglican bishop and so successfully united the Experimental Philosophy with the Church of England in his own career.

103. Thomas Sprat, The History of the Royal-Society of London, for the Improving of Natural Knowledge, facsimile of the 1667 London edition, ed. Jackson I. Cope and Harold Whitmore Jones (St. Louis: Washington University Press, 1958), pp. 35, 372, 378. 
But from the time in which the Real Philosophy has appear'd, there is scarce any whisper remaining of such horrors: Every man is unshaken at these Tales, at which his Ancestors trembled: the cours of things goes quietly along, in its own true channel of Natural Causes and Effects. For this we are beholden to Experiments: which though they have not yet completed the discovery of the true world, yet they have already vanquish'd those wild inhabitants of the false worlds, that us'd to astonish the minds of men. A Blessing for which we ought to be thankful, if we remember, that it is one of the greatest Curses that God pronounces on the wicked, That they shall fear where no fear is. ${ }^{104}$

Christianity had always taught that the advent of Christ had routed the malignant spirits of the pagan world; here we are being told that the Experimental Philosophy has completed the overthrow of the monsters and ended the reign of superstition, which has reached its modern meaning- "fear where no fear is."

Abraham Cowley's "Ode" at the beginning of Sprat's History makes the theme explicit, celebrating the downfall of a monstrous idol. Describing Bacon as a Moses "who from the Mountains Top of his Exalted Wit, Saw [the promis'd land] himself, and shew'd us it," the "Ode" returns to the Eden story, telling us how "Bacon has broken that Scar-crow Deitie ... that monstrous God which stood in the midst of th' Orchard." With the monster gone, "the Orchards open now, and free" for us to enter.

We are left wondering about the identity of "that monstrous God," since no such being appears in the biblical story. Cowley explains the meaning of his term as:

Autority, which did a Body boast,

Though 'twas but Air condens'd, and stalked about,

Like some old Giants more Gigantic Ghost,

To terrifie the Learned Rout.

104. Sprat, pp. 339-41. I first encountered this quote in Brian Easlea, Witch Hunting, Magic and the New Philosophy: An Introduction to the Debates of the Scientific Revolution (Sussex: The Harvester Press, 1980), p. 212. 
But "Autority" seems too bloodless to explain "some old Giants more Gigantic Ghost," with its capacity to "terrifie." Cowley's "Ode" is certainly ambiguous. The only "monstrous God" who appears in the Eden story is the Lord God himself, who walked in the garden "in the cool of the day." ${ }^{05}$ If he has been overthrown, then the serpent's promise of "ye shall become as gods" has been fulfilled-as it has, since now we can freely enter the Garden. In one of his unpublished works, Bacon writes that we are "mortal gods." ${ }^{106}$ The most obvious association with the "monstrous God" in the midst of Cowley's Orchard is the serpent of Eden, Satan (demons were commonly considered able to form bodies out of "Air condens'd"). However we interpret Cowley, it is clear that a demonic force has been overthrown and shown to be essentially unreal, and that this overthrow has opened the doorway to all knowledge. ${ }^{107}$

So great were the changes being worked in how people viewed the world, in both politics and natural philosophy, that it is not surprising that Cowley's allusions were unconsidered and perhaps unconscious on his part. Nor is it surprising that Royal Society thinkers revisited the recent past, as in the GlanvillMore debate of the 1670s on witchcraft. At first, this appears to run counter to our argument. Here were two members of the Royal Society in good standing, devoted to Bacon, calling for research into witchcraft, reprinting the texts of witch-hunters and taking seriously stories and beliefs that Reginald Scot had scorned a century earlier. Robert Boyle interested himself in this debate, writing Glanvill in 1677 that it "will be a good service to religion" to prove the existence of demons through "one circumstantial narrative, fully verified." ${ }^{108}$

This episode is generally interpreted as responding to anxieties about the place of spirit, including the devil and even God, in a world ruled by mechanism. By an interesting inversion, perhaps the devil could be used to demonstrate

105. Genesis 3:8.

106. If we think that Cowley intended these explicitly anti-Christian meanings we are left with a whole new set of problems. If we believe that the Lord God of Eden was a monster needing to be overthrown so that humanity may be free, we are expressing a Gnostic theology directly contrary to the explicit religion of the seventeenth century. The reference is to Farrington, p. 106 ("Redargutio philosophiarum," the most dramatic of Bacon's works).

107. Sprat, B2.

108. Robert Boyle, The Works of the Honourable Robert Boyle, 6 vols., ed. Thomas Birch (London, 1772), microfiche copy, vol. 5, p. 244. 
the existence of God. ${ }^{109}$ A second interpretation involves what Keith Hutchison calls the "radical supernaturalism" of the early mechanical philosophy. ${ }^{110}$ Here I wish only to clarify what kind of spirits the Royal Society was searching for.

Bacon had suggested in the Advancement of Learning that an empirical study of sorcery and witchcraft might reveal new insights about natural causes. ${ }^{111}$ He went into more detail on the subject in his posthumous "natural history," Sylva sylvarum, where he had argued that spirits must be either creatures of the natural world whose existence could be materially demonstrated, or beings from another realm whose existence did not impinge on physical reality, as he had described in his "Confession."112 This opened the possibility that demons, or some demons, might be natural beings susceptible to experimental study, and it was this thinking that impelled Glanvill and More.

Glanvill and More were considering the demonological literature within a new framework, so despite their credulity they were not planning to reinstate any persecution of witches. They were seeking to verify the existence of spirit by "experiment," and the demons they sought were natural creatures. Since demons were more "feculent and gross" than good spirits, they were more attuned to our embodied senses and so better experimental subjects. ${ }^{113}$ If they had previously been hidden in the realm of the occult, all that was about to change as the Royal Society's experimenters shone light into its darkest corners as part of a general attempt to break down the realm of Aristotelian occult causes. ${ }^{114}$ At the same time, Glanvill and More were defensive about the charge that they

109. See Thomas Harmon Jobe, "The Devil in Restoration Science: The Glanvill-Webster Debate," Isis 72 (1981), pp. 343-56.

110. Keith Hutchison, "Supernaturalism and the Mechanical Philosophy," History of Science 21 (1983), pp. 297-98, 327-28. Hutchison's point is that the mechanical philosophy was built on a "radical supernaturalism" that used God's direct agency to define a new order of nature that vacated the Aristotelian qualities, and that this attitude could easily discard its supernatural framework and turn into a comprehensive naturalism, once its basic tenets had become so widely accepted they no longer needed to be consciously set out.

111. Vickers, ed., p. 177.

112. Bacon $C W$, vol 2, pp. 641-58.

113. Joseph Glanvill, Saducismus Triumphatus, or, Full and Plaine Evidence Concerning Witches and Apparitions, facsimile of the 1689 London edition with introduction by Coleman O. Parsons (Gainesville, FL: Scholars' Facsimiles and Reprints, 1966), pp. 91-92.

114. See Clark and Hutchison, notes 2 and 3. 
might be furthering superstition: More appears to be referring to the long passage from Sprat's History quoted above when he writes that while "the wicked fear where no fear is ... he that fears God and has Faith in Jesus Christ need not fear how many Devils there be."115

The devils that the Royal Society wanted to track down were natural, if invisible, inhabitants of the natural world. There are two senses of "natural" here, which need to be distinguished because they show a transition of meaning in that term. The devil had always been a natural creature, in that he was created by God, but he had never been natural in the sense we use the word todaymaterial, subject to material causality, part of everyday reality. As we have seen, Bacon makes the distinction: the devil and the other spirits were created before the natural world, and our souls were created outside the natural world.

The distinction is found in Robert Boyle. His chief philosophical work is devoted to showing how the classical concept of "nature," by which he means a world penetrated by spirit or consciousness, is a form of idolatry prejudicial to the glory of the God and the discovery of his works. God's glory is far better served when we view the world "as a great and ... pregnant automaton." 116 Such an automaton might have a place for demons, if by that was meant "animals" composed of some attenuated spirituous substance. ${ }^{117}$ But it had no place for the agency of the devil as traditionally understood, as the lord of magical effects. In demonstrating that the mechanical philosophy was the most convincing way to explain natural phenomena, Boyle explicitly equates belief in the "vulgarly received notion of nature" with belief in the devil's magical power, writing that those who believe "nature" is able "to move bodies in another than a physical way" are making an error equivalent to thinking that "those strange diseases that divers very learned and sober physicians impute to witchcraft" are in fact "produced by a wicked immaterial spirit called a devil."118

115. Glanvill, p. 27.

116. Robert Boyle, A Free Enquiry into the Vulgarly Received Notion of Nature, ed. Edward B. Davis and Michael Hunter (Cambridge: Cambridge University Press, 1996), pp. 45-57, 41, 15, 40.

117. Glanvill, p. 196.

118. Robert Boyle, Free Enquiry, p. 145. This condemnation extended to witchcraft: in an early letter, Boyle had dismissed a book that attributed urinary incontinence to witchcraft: "I cannot but wonder (the author) should confidently ascribe so prodigious a disease to witchcraft." See Boyle, Works, vol. 1, p. 527. 
At the same time as he wrote this, Boyle continued to believe in the devil's spiritual reality. He was an intensely religious man, who throughout his life wrote "occasional reflections" on religious themes, and two of these concern the devil. ${ }^{119}$

\section{Conclusions and next steps}

It remained too dangerous to deny the devil's existence altogether, as witness the intensity of the controversy ignited by Balthasar Bekker in the 1690s. ${ }^{120}$ But it concludes our argument to note that Newton believed that the devil was only a metaphor, a way to conceptualize the evil passions of men's hearts. By the 1680s, as shown by Stephen David Snobelen, Newton had reached the unequivocal position that any biblical references to the devil did not signify a real being, but were intended only as symbols of "the spirit of error delusion \& inordinate affections reigning in the world." Demons were equally unreal, so that "to beleive that men or weomen can really divine, charm, inchant, bewitch or converse with spirits is a superstition of the same nature $\mathrm{w}^{\text {th }}$ beleiving that the idols of the gentils were not vanities but had spirits really seated in them." ${ }^{121}$ Belief in the devil was superstitious and a form of idolatry (and a vanity too). ${ }^{122}$

The effort between 1400 and 1700 to reform Christian doctrine focused largely on superstition. This campaign against superstition pushed the devil to the forefront as the ultimate author and source of all superstition, idolatry, and vain observance; but in the end its logic was to overthrow his kingdom. It helped provoke a more systematic philosophy of nature that revised

119. Boyle, Works, vol. 2, pp. 162, 182-87.

120. Jonathan I. Israel, Radical Enlightenment: Philosophy and the Making of Modernity 1650-1750 (Oxford: Oxford University Press, 2001), p. 382.

121. Stephen David Snobelen, "Lust, Pride, and Ambition: Isaac Newton and the Devil," in Newton and Newtonianism: New Studies, ed. James E. Force and Sarah Hutton (Dordrecht / Boston / London: Kluwer, 2004), p. 163.

122. Newton's position was similar to mainstream Rabbinic theology. Babylonian Talmud, Baba Bathra 16a, states that "Satan, the evil inclination and the Angel of Death, are all one"; see A. P. Hayman, "Rabbinic Judaism and the Problem of Evil," Scottish Journal of Theology 29 (1976), p. 470. The thought was cited by Moses Maimonides in his Guide for the Perplexed, written at the end of the twelfth century; see Moses Maimonides, The Guide for the Perplexed, trans. M. Friedlander (New York: Dover, 1956), p. 298. Newton's interest in Maimonides is well recognized. 
superstition, by excluding the devil from nature. This new philosophy of nature had many roots, but a need to reject superstitious thinking was clearly one of them, with the result that belief in the devil's agency became regarded as a fine and summative example of superstitious thinking. The witch hunt raised the devil up in might, but then it raised so many questions that it provided the occasion to strip him of his powers, eventually leaving him only a spiritual agency that could not touch the world. Superstition was redefined until it became the opposite of the new experimental philosophy, the concept used to describe the matter out of which it had grown and to provide the picture of what it stood against. A large part of the "boundary work" described by Henry as part of his fragmentation process involved wrestling with the devil's agency and defining as superstition all beliefs that depended on it. This helped define the remnant occult tradition as nothing but superstition, which remains the antonym of science today. ${ }^{123}$

And superstition was gendered. Witchcraft was generally a crime of women, especially in England. ${ }^{124}$ The strong association of witchcraft with superstition was summed up in the common term "old wyves tales," 125 and helped make superstition something associated with the feminine, just as the new philosophy was described by Bacon, Sprat, and others as strong and "masculine." ${ }^{26}$ Meanwhile, the synonyms "idolatry" and "superstition" diverged in connotation. In Bacon's day they were linked, with idolatry the stronger and more general term, but then they moved apart, with idolatry retaining its "high" and therefore more abstract religious signification. As it became a concept increasingly specialized to religion, its signification was narrowed by the gradual

123. For example, see Carl Sagan, The Demon-Haunted World: Science as a Candle in the Dark (New York: Random House, 1995).

124. See James A. Sharpe, "Witchcraft and Women in Seventeenth-Century England: Some Northern Evidence," Continuity and Change 6 (1991), pp. 179-99.

125. See, for example, Thomas Hobbes, Leviathan, ed. C. B. MacPherson (Harmondsworth: Penguin, 1968), pp. 629, 713, 714. Superstitio is a feminine noun in Latin and its descendant remains feminine in all romance languages.

126. See Bacon, Temporis partus masculus (“The Masculine Birth of Time”), in Farrington, pp. 62, 72; Sprat, pp. 40, 124, 129, 415. This opposition supports the masculine bias of science argued by Carolyn Merchant, Brian Easlea, David Noble, and others. See Brian Easlea, Witch Hunting, Magic and the New Philosophy; Carolyn Merchant, The Death of Nature (New York: HarperCollins, 1979); David F. Noble, A World with Women: The Christian Clerical Culture of Western Science (New York: Alfred A Knopf, 1992). See also Clark, pp. 123-33. 
secularization of society. In contrast, superstition pointed to so many concrete referents in popular belief and practice that it retained a broad meaning as the opposite to enlightened thinking. ${ }^{127}$

Author's note: I would like to thank Libby Cohen, without whose encouragement I would not have continued, and the anonymous reviewers, whose thoughtful comments led to much improvement.

127. The devil held his grip on the deepest levels of the imagination. John Milton's Paradise Lost was published in its first edition in the same year as Sprat's History, 1667. 